Reprod. Nutr. Dévelop., 1986, 26 (4),921 -932.

\title{
Steroid secretion by foetal mammal gonads and its regulation by gonadotrophins
}

\author{
J.-P. WENIGER
}

Laboratoire de Zoologie et d'Embryologie expérimentale, Université Louis-Pasteur,

12, rue de I'Université, 67000 Strasbourg, France.

\section{Introduction.}

Castration, grafting and substitution experiments performed by Jost (1946-47) in rabbits first demonstrated that the testis controlled male sex differentiation in foetal mammals by a mechanism involving androgen secretion. Later experiments by Jost (1951) suppressing the hypophysis of rabbit foetuses by intrauterine decapitation and giving pregnant mare serum gonadotrophin to the decapitated foetuses showed that this androgen secretion was regulated by pituitary gonadotrophin. These early studies gave no cause to suspect an hormonal function of the ovary, and it was not until 1977 that oestrogen formation by the foetal ovary was established (Milewich et al., 1977).

Since Acevedo et al. (1963) first demonstrated by radiochemical methods that the human foetal testis formed testosterone and androstenedione, the secretion of steroids by foetal mammal gonads and its regulation by gonadotrophins have been the subject of numerous investigations. The purpose of the present paper is to review these studies and to stress the points which need particular attention.

\section{A. The testis}

\section{Androgen production.}

a. Effect of $L H$ on testosterone secretion. - The stimulatory effect of $\mathrm{LH}$ on androgen production by the foetal testis in vitro - testosterone is the main androgen secreted - has been demonstrated in a great variety of mammalian species (table 1). The foetal testis also responds in vivo to injected LH or hCG by increased testosterone secretion. This has been shown in rabbits and rhesus monkeys. Testicular testosterone content and plasma testosterone concentration in the 29-day old rabbit foetus rose 3-fold $30 \mathrm{~min}$ after $\mathrm{LH}$ was injected into the umbilical vein (Veyssière et al., 1977). One hour after the injection of $100 \mathrm{IU}$ of 
hCG into the foetal circulation of the rhesus monkey in late gestation, the serum testosterone level had increased 6-fold (Huhtaniemi et al., 1977b).

b. Secretion of $\angle H$ in utero. - After testis responsiveness to $\mathrm{LH}$ in utero had been demonstrated, the next logical question was whether the foetal hypophysis secreted $\mathrm{LH}$ which could stimulate testosterone secretion.

$\mathrm{LH}$ was detectable by radioimmunoassay in the culture media of pituitaries from 13 to 18-week old human foetuses (Groom et al., 1971), from those as young as 7 weeks old (Siler-Khodr et al., 1974) or from those 10 to 19 weeks old (Goodyer et al., 1977). LH was measurable in the pituitary of foetuses as early as 10 weeks of gestation, the youngest stage studied (Hagen and McNeilly, 1975 ; Kaplan and Grumbach, 1976 ; Clements et al., 1976). Immunoreactive LH was first detectable in the serum by 12 weeks of gestation (Reyes et al., 1974 ; Kaplan and Grumbach, 1976 ; Clements et al., 1976 ; Hagen and McNeilly, 1977). The $\beta$-LH subunit responsible for biological activity could not be revealed in the pituitary by immunohistochemistry before the 15th week (Bugnon et al., 1977). Taken together, those results indicated that the human foetal pituitary began secreting $\mathrm{LH}$ at 10 to 12 weeks.

TABLE 1

Stimulation of testosterone secretion by $L H$ or $h C G$ in the foetal testis of mammals in vitro.

\begin{tabular}{|c|c|}
\hline Species & Authors \\
\hline Human & $\begin{array}{l}\text { Abramovich et al. (1974) } \\
\text { Ahluwalia et al. (1974) } \\
\text { Huhtaniemi et al. (1977a) }\end{array}$ \\
\hline Mouse & $\begin{array}{l}\text { Weniger and Zeis (1974 and 1975b) } \\
\text { Pointis and Mahoudeau }(1975,1977 \text { and 1979) }\end{array}$ \\
\hline Rat & $\begin{array}{l}\text { Warren et al. (1975) } \\
\text { Weniger and Zeis (1975a and b) } \\
\text { Picon and Ktorza (1976) } \\
\text { Sanyal and Villee (1977) } \\
\text { Picon and Gangnerau (1979 and 1980) } \\
\text { Paz et al. (1980) }\end{array}$ \\
\hline Bovine & $\begin{array}{l}\text { Kiser et al. (1975) } \\
\text { Shemesh et al. (1978) }\end{array}$ \\
\hline Sheep & Mauléon et al. (1977) \\
\hline Rhesus monkey & Huhtaniemi et al. $(1977 \mathrm{~b})$ \\
\hline Rabbit & $\begin{array}{l}\text { George et al. (1978) } \\
\text { Veyssière et al. (1980b) }\end{array}$ \\
\hline Guinea-pig & Brinkmann and van Straalen (1979) \\
\hline Pig & Raeside and Middleton (1979) \\
\hline
\end{tabular}


The pituitary of bovine foetuses was found to contain increasing quantities of LH during and after the 3-month stage of gestation, the earliest stage studied, and to synthesize significant amounts of the hormone in vitro (Oxender et al., 1972a). No significant difference was observed between the sexes (Workewych and Cheng, 1979). LH was already measurable in the serum of 3-month old foetuses (Oxender et al., 1972b).

LH was measurable in both the pituitary and the serum of foetal lambs from day 55 to term (Foster et al., 1972a, b).

The concentration of $\mathrm{LH}$ in guinea pigs from day 50 of gestation, the earliest stage studied, was greater in the foetal plasma than in the maternal circulation. This was proof that the foetal hypophysis secreted LH from this stage (Donovan et al., 1975).

$\mathrm{LH}$ was undetectable in the serum of 49 to 80 -day old pig foetuses. After that stage, it could be measured and its concentration was substantially higher than in the maternal circulation (Colenbrander et al., 1977).

When both the pituitary and testis of 18-day old mouse foetuses were placed together in organ culture, testosterone release into the medium increased 5 -fold (Pointis and Mahoudeau, 1975, 1976). A significant rise in testosterone secretion was also observed with the pituitary and testis of 16-day old foetuses, but not with 14-day old ones (Pointis and Mahoudeau, 1977). However, LH was already detectable in the pituitary at the 14-day stage, but not measurable in the plasma before the 16-day stage (Pointis et al., 1980). Disregarding the slight differences in the results, it can be concluded that LH is first secreted in the mouse foetus between days 14 and 16 .

Pituitary LH was first detected in the male rat foetus on day 17 of gestation : high levels of serum LH had already been found on day 16 (Chowdhury and Steinberger, 1976). The cells containing LH were recognizable from day 18 by immunohistochemistry (Setáló and Nakane, 1976; Tougard et al., 1977 ; Watanabe and Daikoku, 1979). So the 17-day stage can be considered as the time when LH secretion begins in the rat foetus.

When both the pituitary and testis of 20-day old rabbit foetuses were put together in organ culture, a 5-fold augmentation in testosterone production was observed (Veyssière et al., 1980a). Nineteen-day old pituitaries, but not 18-day ones, significantly increased testosterone production by 20 -day old testes (Veyssière et al., 1980b). LH was first detectable in the pituitary of 19-day old foetuses (Veyssière et al., 1981, 1982). So, it can be concluded that the beginning of $\mathrm{LH}$ secretion in the rabbit foetus coincides with the 19-day stage.

Pituitary LH concentrations in foetal ponies increase between days 90 and 150 of pregnancy and then remain constant. Blood LH concentrations are highest between days 100 and 150 (Wesson and Ginther, 1980).

The level of serum LH in male rhesus monkey foetuses remains relatively low throughout gestation, but it is higher than in the maternal circulation (Ellinwood and Resko, 1980).

c. Autonomous onset of testosterone secretion. - The question arose whether the onset of testosterone secretion by the foetal testis was dependent on 
TABLE 2

Time of onset of testosterone secretion by the foetal testis.

\begin{tabular}{lll}
\hline \multicolumn{1}{c}{ Species } & \multicolumn{1}{c}{ Gestational age } & \multicolumn{1}{c}{ Authors } \\
\hline Mouse & 12 days & Weniger and Zeis (1972 and 1975b) \\
\hline Rat & 15 days & $\begin{array}{l}\text { Warren et al. (1973) } \\
\text { Weniger and Zeis (1975a and b) } \\
\text { Picon (1976) } \\
\text { Feldman and Bloch (1978) } \\
\text { Picon et al. (1982) }\end{array}$ \\
\hline Rabbit & 17 to 19 days & $\begin{array}{l}\text { Wilson and Siiteri (1973) } \\
\text { George } \text { et al. (1979) }\end{array}$ \\
\hline Human & 18 days & Siiteri and Wilson (1974) \\
\hline Pig & 8 to 10 weeks & $\begin{array}{l}\text { Raeside and Sigman (1975) } \\
\text { Raesides and Middleton (1979) }\end{array}$ \\
\hline Guinea-pig & 27 days & Brinkmann (1977) \\
\hline
\end{tabular}

or independent of LH stimulation. The time of the onset of testosterone secretion by the foetal testis in the most studied species is given in table 2. A comparison of the data in table 3 favours the conclusion that testosterone secretion, at its onset, is independent of LH. Later on, it comes under LH control, as shown in the rat foetus by decapitation experiments. It should be added that testosterone

TABLE 3

Time of onset of testosterone and $L H$ secretion in foetal mammals.

\begin{tabular}{lll}
\hline \multicolumn{1}{c}{ Species } & \multicolumn{1}{c}{ Testosterone secretion } & LH secretion \\
\hline Mouse & 12 days & 14 to 16 days \\
Rat & 15 days & 17 days \\
Rabbit & 17 to 19 days & 19 days \\
Human & 8 to 10 weeks & 10 to 12 weeks \\
\hline
\end{tabular}

secretion in the human foetal testis may be initiated by hCG (Winter et al., 1981), although the presence of LH/hCG receptors before week 8 of gestation has to be demonstrated.

d. Control of testosterone secretion by $\mathrm{LH}$. - The testes from 20-day old rat foetuses decapitated 1 day earlier produced 5 -fold less testosterone in vitro than control testes. When decapitation was performed on day 20 , testosterone production measured on day 21 had decreased 8-fold (Weniger et al., 1977; Naessany et al., 1981). LH given to the foetus at the time of decapitation restored 
normal testosterone production (Chouraqui et al., 1977). Decapitation on day 18 did not alter testosterone production on day 19 (Habert and Picon, 1982). So, testosterone secretion by foetal rat testes is regulated by LH from 19 days on.

e. Hypothalamo-pituitary-testicular interrelationships. - The next studies tried to determine the existence of an inhibitory action of testosterone on LH secretion. After 3 injections of dihydrotestosterone to pregnant rabbits at 12-hour intervals, the testicular testosterone content measured $5 \mathrm{~h}$ after the last injection had not varied in comparison with control values when the foetuses were sacrificed at 23 days, but it had decreased by one-half at 25 days. So, a negative feedback mechanism of testosterone on LH secretion is established in rabbit foetuses between days 23 and 25 (Veyssière et al., 1980a).

A similar reduction in the testosterone content of foetal testes was observed after testosterone injection to pregnant rats (Naessany et al., 1981); this negative feedback becomes effective on day 19 (Naessany and Picon, 1982).

That a drop in serum testosterone results in an increase in $\mathrm{LH}$ secretion has been demonstrated in rhesus monkey foetuses. Three weeks after orchiectomy on day 100 , the serum LH concentration rose 10-fold (Ellinwood et al., 1982). So, the existence of testicular-pituitary interrelationships is a well-established feature in mammalian foetuses.

These relationships probably extend to the hypothalamus, as is suggested by the following results. In 6-month old bovine foetuses, a 2-fold increase in serum testosterone concentration was observed $3 \mathrm{~h}$ after $\mathrm{GnRH}$ injection (Kiser et al., 1975). In 4 to 5 -month old rhesus monkey foetuses, mean serum testosterone concentration had increased 2 to 2.5 -fold by 1 hour after $\mathrm{GnRH}$ administration (Huhtaniemi et al., 1977b; Norman and Spies, 1979). In 29-day old rabbit foetuses, the plasma testosterone level had risen 8-fold and the testicular testosterone content 3.5 -fold by $30 \mathrm{~min}$ after $\mathrm{GnRH}$ injection (Veyssière et al., 1977).

\section{Oestrogen production.}

a. By foetal testis. - The aromatization of ${ }^{3} \mathrm{H}$-labelled androgens by the 19 to 20-day old foetal rat testis has been reported by Weniger and Zeis (1983, 1985). The regulation of this process by gonadotrophins is under current investigation.

b. By immature testis. - Results of experiments with testes from immature rats are interesting (Tsai-Morris et al., 1985). In 5-day old neonatal rats, aromatase activity, measured by the ${ }^{3} \mathrm{H} \mathrm{H}_{2} \mathrm{O}$ release method, is as high in isolated Leydig cells as in isolated Sertoli cells. At the age of 15 days, it is twice as high in Leydig cells as in Sertoli cells. At 60 days, the ratio is $5: 1$. So, aromatase activity increases with age in Leydig cells and decreases in Sertoli cells.

These results of Tsai-Morris et al. (1985) confirm results obtained previously in limited studies. For instance, FSH, (but not LH) increased cAMP levels in 
Sertoli cell preparations from 18 to 20-day old rats (Dorrington et al., 1975a). FSH and CAMP (but not LH) greatly stimulated the conversion of exogenous testosterone into oestradiol in Sertoli cell aggregates from 10 to 20-day old rats cultured for 4 to $48 \mathrm{~h}$ (Dorrington and Armstrong, 1975a, b, 1979 ; Verhoeven et al., 1979 ; Gore-Langton et al., 1980 ; Suárez-Quian et al., 1983). So, it is established that Sertoli cells from 5 to 20 -day old rats possess aromatase activity, which can be stimulated by FSH. The production of oestradiol by the Leydig cells has been less thoroughly investigated. However, the results of Tsai-Morris et al. (1985) clearly show that aromatase activity exists in Leydig cells and can be stimulated by hCG.

\section{B. The ovary}

\section{Androgen production.}

a. By foetal ovary. - LH or hCG markedly stimulated the secretion of androgens by 32 to 37 -day old foetal pig ovaries in vitro. These androgens were formed from endogenous or exogenous precursors. Androstenedione was formed almost exclusively, testosterone amounting to less than $5 \%$ (Raeside, 1983).

b. By immature ovary. - Studies in immature animals confirm the stimulatory effect of $\mathrm{LH}$ on androgen secretion. Seven-day old mouse ovaries formed mostly androstenedione (Fortune and Eppig, 1979), while 25-day old hamster ovaries formed approximately equal amounts of testosterone and androstenedione (Shaha and Greenwald, 1983).

In immature hamster ovaries, the conversion of androstenedione into testosterone was enhanced under the influence of FSH which stimulated $17 \beta$ hydroxysteroid-dehydrogenase activity. $5 \alpha$-Reductase activity was enhanced by LH (Tsuji et al., 1983).

\section{Oestrogen production.}

a. By immature ovary. - It is preferable to begin by analysing experiments on prepubertal ovaries.

The fundamental work is that of Moon et al. (1975). These authors showed that ovaries from 28-day old hypophysectomized rats cultured in Medium 199 secreted oestradiol into the culture medium. The addition of testosterone was virtually without effect. On the contrary, FSH produced a 2 to 3 -fold increase in œstradiol secretion. In the presence of $0.5 \mu \mathrm{M}$ testosterone as a substrate, FSH had a still greater effect and enhanced oestradiol production 8 to 10-fold. It was concluded that FSH stimulated aromatization. 
In subsequent experiments, the same authors (Dorrington et al., 1975b) showed that granulosa cells isolated from the ovaries of hypophysectomized 29day old rats secreted only negligible quantities of oestradiol in the absence of both testosterone and FSH. The addition of testosterone or FSH separately to the culture medium did not influence oestradiol production. However, the addition of both substances greatly enhanced oestradiol secretion. Oestrone was produced too, but at levels only 10 to $30 \%$ as high as oestradiol. Taking into acount these results and those of the previous work, it was concluded that granulosa cells needed both androgen precursors provided by theca and/or interstitial cells and FSH which specifically stimulates the aromatizing enzyme system.

The results of Dorrington et al. (1975b) were confirmed by Erickson and Hsueh (1978). In the absence of androstenedione as a substrate, no significant stimulation of oestrogen secretion was observed in FSH-treated granulosa cell cultures. However, in the presence of androstenedione, FSH stimulated oestrogen production 9 and 40 -fold after 1 and 2 days, respectively.

Funkenstein and Nimrod (1983) studied the steroidogenic capabilities of 4-day old rat ovaries in organ culture. In the presence of $3 \mu \mathrm{M}$ testosterone, there was significant œstradiol production which increased 4-fold when $(\mathrm{Bu})_{2} \mathrm{CAMP}$ was added to the medium. Oestrone was not measured.

In neonatal mouse ovaries, oestradiol secretion was stimulated by $\mathrm{FSH}$ at the 7-day stage but not at the 2-day stage (Fortune and Eppig, 1979).

b. By foetal ovary. - The first of a series of studies on oestrogen formation by the foetal ovary of mammals was that of Milewich et al. (1977) in rabbits. These authors determined the conversion percentages of $0.5 \mu \mathrm{M} 3 \mathrm{H}$-testosterone or ${ }^{3} \mathrm{H}$-androstenedione to oestrone and oestradiol by the 19-day old ovary in vitro. The ratios of oestradiol to oestrone formed from testosterone and androstenedione, respectively, were 15 and 7.5. Using the same methods, George and Wilson (1978) found that the ovary of the 12.5 to $13.8-\mathrm{cm}$ CR length human foetus also formed more oestradiol than oestrone; the ratio was about 2 with androstenedione as the substrate and 8 with testosterone.

According to Terada et al. (1984), aromatization of ${ }^{3} \mathrm{H}$-androstenedione could not be effected by the 18-day old mouse ovary in organ culture. However, in the presence of FSH, the production of oestrone and oestradiol was already detected at the 17-day stage, when equal amounts of both oestrogens were formed.

When oestrogen production by the 19 to 20-day old foetal rat ovary was investigated, it was found that appreciable amounts of oestrone were formed from either testosterone or progesterone, even in the absence of FSH ; virtually no oestradiol was formed (Weniger et al., 1984). The effect of FSH was studied in the 19-day old ovary: a stimulatory effect on oestrogen formation with either progesterone, dehydroepiandrosterone, testosterone or androstenedione could not be demonstrated (Weniger et al., 1985). However, Picon et al. (1985) found that FSH enhanced the aromatase activity of the 20-day old ovary.

For the time being, the case of the foetal rat ovary appears to be unique as regards the prevalence of the formation of oestrone over that of oestradiol. Since, according to Dorrington et al. (1975b), the production of oestradiol is 3 to 
10 -fold as high as that of oestrone at the 29-day stage after birth, a shift must occur between that stage and the late foetal stages. It will be interesting to determine a more exact timing for this shift. On the other hand, the stimulatory effect of FSH on aromatase activity in the foetal mouse and rat ovary needs to be confirmed.

\section{Conclusion.}

Gonado-pituitary interrelationships already exist during foetal life in mammals. At its onset, androgen secretion by the foetal testis is independent of pituitary LH but, later, it comes under LH control. Testosterone exerts a retroinhibition on $\mathrm{LH}$ secretion. On the other hand, oestrogen secretion by the foetal testis has been demonstrated.

The ovary secretes androgens as well as oestrogens. An interesting feature of the rat ovary is the shift from oestrone to oestradiol secretion between foetal and prepubertal life. The stimulatory effect of FSH on the aromatizing enzyme system in the ovary has been shown in some studies but not in others.

Reçu en décembre 1985. Accepté en avril 1986.

Résumé. Sécrétion de stérö̈des par les gonades foetales de mammifères.

Les principales conclusions qui se dégagent de la présente mise au point sont les suivantes.

Des corrélations hypophyso-gonadiques existent dès la vie fotale chez les mammifères. A l'origine, la sécrétion de testostérone par le testicule fœtal est indépendante d'une stimulation hypophysaire, mais elle tombe sous la dépendance de LH avant la fin de la vie fœtale. La testostérone exerce une rétroaction inhibitrice sur la sécrétion de LH. D'autre part, on a démontré la sécrétion d'œstradiol par le testicule fœtal.

L'ovaire sécrète à la fois des androgènes et des cestrogènes. Chez le rat, il est intéressant de noter le passage d'une prédominance de sécrétion d'œstrone à une prévalence de sécrétion d'œstradiol entre le stade fœetal et le stade de la maturité sexuelle. L'action stimulatrice de FSH sur l'aromatase de l'ovaire fœtal est controversée.

\section{References}

ABRAMOVICH D. R., BAKER T. G., NEAL P., 1974. Effect of human chorionic gonadotrophin on testosterone secretion by the foetal human testis in organ culture. J. Endocrin., 60, 179185.

ACEVEDO H. F., AXELROD L. R., ISHIKAWA E., TAKAKI, F. 1963. Studies in fetal metabolism. II. Metabolism of progesterone-4- ${ }^{14} \mathrm{C}$ - and pregnenolone- $73-{ }^{3} \mathrm{H}$ in human fetal testes. $J$. clin. Endocrin., 23, 885-890.

AHLUWALIA B., WILLIAMS J., VERMA P., 1974. In vitro testosterone biosynthesis in the human fetal testis. II. Stimulation by cyclic AMP and human chorionic gonadotropin (hCG). Endocrinology, 95, 1411-1415

BRINKMANN A. O., 1977. Testosterone synthesis in vitro by the fetal testis of the guinea pig. Steroids, 29, 861-873. 
BRINKMANN A. O., VAN STRAALEN R. J. C., 1979. Development of the LH-response in fetal guinea pig testes. Biol. Reprod., 21, 991-997.

BUGNON C., BLOCH B., FELLMANN D., 1977. Cyto-immunological study of the ontogenesis of the gonadotropic hypothalamo-pituitary axis in the human fetus. J. Steroid Biochem., 8, $565-575$.

CHOURAQUI J., ZEIS A., WENIGER J.-P., 1977. Corrélations hypophyso-testiculaires chez l'embryon de Rat. C.R. Acad. Sci. Paris, 285, Sér. D, 1475-1478.

CHOWDHURY M., STEINBERGER E., 1976. Pituitary and plasma levels of gonadotrophins in foetal and newborn male and female rats. J. Endocrin., 69, 381-384.

CLEMENTS J. A., REYES F. I., WINTER J. S. D., FAIMAN C., 1976. Studies on human sexual development. III. Fetal pituitary, serum and amniotic fluid concentrations of LH, CG and FSH. J. clin. Endocrin. Metab., 42, 9-19.

COLENBRANDER B., KRUIP Th. A. M., DIELEMAN S. J., WENSING C. J. G., 1977. Changes in serum LH concentrations during normal and abnormal sexual development in the pig. Biol. Reprod., 17, 506-513.

DONOVAN B. T., ter HAAR M. B., LOCKHART A. N., MCKINNON P. C. B., MATTOCK J. M., PEDDIE M. J., 1975. Changes in the concentration of luteinizing hormone in plasma during development in the guinea-pig. J. Endocrin., 64, 511-520.

DORRINGTON J. H., ARMSTRONG D. T., 1975. Follicle-stimulating hormone stimulates estradiol-17 $\beta$ synthesis in cultured Sertoli cells. Proc. nat. Acad. Sci. USA, 72, 2677-2681.

DORRINGTON J. H., ARMSTRONG D. T., 1979. Effects of FSH on gonadal functions. Rec. Progr. Horm. Res., 35, 301-342.

DORRINGTON J. H., MOON Y. S., ARMSTRONG D. T., 1975b. Estradiol-17 $\beta$ biosyntesis in cultured granulosa cells from hypophysectomized immature rats : stimulation by folliclestimulating hormone. Endocrinology, 97, 1328-1331.

DORRINGTON J. H., ROLLER N. F., FRITZ I. B., 1975a. Effects of follicle-stimulating hormone on cultures of Sertoli cell preparations. Mol. cell. Endocrin., 3, 57-70.

ELLINWOOD W. E., RESKO J. A., 1980. Sex differences in biologically active and immunoreactive gonadotropins in the fetal circulation of rhesus monkeys. Endocrinology, 107, 902907.

ELLINWOOD W. E., BAUGHMAN W. L., RESKO J. A., 1982. The effects of gonadectomy and testosterone treatment on luteinizing hormone secretion in fetal rhesus monkeys. Endocrinologv, 110, 183-189.

ERICKSON G. F., HSUEH A. J. W., 1978. Stimulation of aromatase activity by follicle-stimulating hormone in rat granulosa cells in vivo and in vitro. Endocrinology, 102, 1275-1282.

FELDMAN S. C., BLOCH E., 1978. Developmental pattern of testosterone synthesis by fetal rat testes in response to luteinizing hormone. Endocrinology, 102, 999-1007.

FORTUNE J. E., EPPIG J. J., 1979. Effects of gonadotropins on steroid secretion by infantile and juvenile mouse ovaries in vitro. Endocrinology, 105, 760-768.

FOSTER D. L., ROACH J. F., KARSCH F. J., NORTON H. W., COOK B., NALBANDOV A. V., 1972a. Regulation of luteinizing hormone in the fetal and neonatal lamb. I. LH concentrations in blood and pituitary. Endocrinology, 90, 102-111.

FOSTER D. L., KARSCH F. J., NALBANDOV A. V., 1972b. Regulation of luteinizing hormone (LH) in the fetal and neonatal lamb. II. Study of placental transfer of LH in the sheep. Endocrinology, 90, 589-592.

FUNKENSTEIN B., NIMROD A., 1983. The dynamics of activation of steroidogenic pathways in cultured neonatal rat ovaries. J. Ster. Biochem. 18, 353-356.

GEORGE F. W., CATT K. J., NEAVES W. B., WILSON J. D., 1978. Studies on the regulation of testosterone synthesis in the fetal rabbit testis. Endocrinology, 102, 665-673.

GEORGE F. W., WILSON J. D., 1978. Conversion of andrugen to estrogen by the human fetal ovary. J. clin. Endocrin. Metab., 47, 550-555.

GEORGE F. W., SIMPSON E. R., MILEWICH L., WILSON J. D., 1979. Studies on the regulation of the onset of steroid hormone biosynthesis in fetal rabbit gonads. Endocrinologv, 105, 1100-1106.

GOODYER C. G., HALL C. S. G., GUYDA H., ROBERT F., GIROUD C. J.-P., 1977. Human fetal pituitary in culture: Hormone secretion and response to somatostatin, luteinizing-hormone 
releasing factor, thyrotropin-releasing factor and dibutyryl cyclic AMP. J. clin. Endocrin. Metab., 45, 73-85.

GORE-LANGTON R., MCKERACHER H., DORRINGTON J., 1980. An alternative method for the study of follicle-stimulating hormone effects on aromatase activity in Sertoli cell cultures. Endocrinology, 107, 464-471.

GROOM G. V., GROOM M. A., COOKE I. D., BOYNS A. R., 1971. The secretion of immunoreactive luteinizing hormone and follicle-stimulating hormone by the human foetal pituitary in organ culture. J. Endocrin., 49, 335-344.

HABERT R., PICON R., 1982. Control of testicular steroidogenesis in fœetal rat : effect of decapitation on testosterone and plasma luteinizing hormone-like activity. Acta endocrin., 99, 466-473.

HAGEN C., MICNEILLY A. S., 1975. Identification of human luteinizing hormone, folliclestimulating hormone, luteinizing hormone $\beta$-subunit and gonadotrophin $\alpha$-subunit in foetal and adult pituitary glands. J. Endocrin., 67, 49-57.

HAGEN C., MCNEILLY A. S., 1977. The gonadotrophins and their subunits in foetal pituitary glands and circulation. J. Ster. Biochem., 8, 537-544.

HUHTANIEMI I. T., KORENBROT C. C., JAFFE R. B., 1977a. hCG binding and stimulation of testosterone biosynthesis in the human fetal testis. J. clin. Endocrin. Metab., 44, 963-967.

HUHTANIEMI I. T., KORENBROT C. C., SERON-FERRE M., FOSTER D. B., PARER J. T., JAFFE R. B., 1977b. Stimulation of testosterone production in vivo and in vitro in the male rhesus monkey fetus in late gestation. Endocrinology, 100, 839-844.

JOST A., 1946-47. Recherches sur la différenciation sexuelle de l'embryon de Lapin. III. Rôle des gonades foetales dans la différenciation sexuelle somatique. Arch. Anat. micr. Morph. exp., 36, 271-315.

JOST A., 1951. Recherches sur la différenciation sexuelle de l'embryon de Lapin. IV. Organogenèse sexuelle masculine après décapitation du fœtus. Arch. Anat. micr. Morph. exp., 40, 247-281.

KAPLAN S. L., GRUMBACH M. M., 1976. The ontogenesis of human foetal hormones. II. Luteinizing hormone (LH) and follicle-stimulating hormone (FSH). Acta Endocrin., 81, 808829 .

KISER T. E., CONVEY E. M., LIN Y. C., OXENDER W. D., 1975. Luteinizing hormone and androgens in the bovine fetus after gonadotropin-releasing hormone. Proc. Soc. exp. Biol. Med., 149, 785-789.

MAULĖON P., BÉZARD J., TEROUI M., 1977. Very early and transient $17 \beta$-estradiol secretion by fetal sheep ovary. In vitru study. Ann. Biol. anim. Bioch. Biophys., 17, 399-401.

MILEWICH L., GEORGE F. W., WILSON J. D., 1977. Estrogen formation by the ovary of the rabbit embryo. Endocrinology, 100, 187-196.

MOON Y. S., DORRINGTON J. H., ARMSTRONG D. T., 1975. Stimulatory action of folliclestimulating hormone on oestradiol-17 $\beta$ secretion by hypophysectomized rat ovaries in organ culture. Endocrinology, 97, 244-247.

NAESSANY S., HABERT R., PICON R., 1981. Effect of androgen injections and decapitation on the pituitary-gonadal axis and genital tract of fetal rats at the end of gestation. J. Endocrin., 88, 359-366.

NAESSANY S., PICON R., 1982. Onset of a feedback inhibition by testosterone in male rat fetuses. Biol. Neonate, 41, 234-239.

NORMAN R. L., SPIES H. G., 1979. Effect of luteinizing hormone-releasing hormone on the pituitary-gonadal axis in fetal and infant rhesus monkeys. Endocrinology, 105, 655-659.

OXENDER. W. D., CONVEY E. M., HAFS H. D., 1972a, Bovine fetal pituitary concentration and in vitro synthesis of prolactin, GH and LH. Proc. Soc. exp. Biol. Med., 139, 1017-1021.

OXENDER W. D., HAFS H. D., INGALLS W. G., 1972b. Serum growth hormone, LH and prolactin in the bovine fetus and neonate. $J$. anim. Sci, 35, 56-61.

PAZ G. F., THLIVERIS J. A., WINTER J. S. D., REYES F. I., FAIMAN C., 1980. Hormonal control of testosterone secretion by the fetal rat testis in organ culture. Biol. Reprod., 23, 1087-1095.

PICON R., 1976. Testosterone secretion by foetal rat testes in vitro. J. Endocrin., 71, 231-238.

PICON R., GANGNERAU M. N., 1979. Synthesis and secretion of testosterone by foetal rat testes : effect of dibutyryl cyclic AMP and comparison with LH. J. Ster. Biochem., 10, 61-66. 
PICON R., GANGNERAU M. N., 1980. Acquisition of sensitivity to LH in relation to foetal development : stimulation of cyclic AMP and testosterone production in the rat testis. Mol. cell. Endocrin., 18, 137-150.

PICON R., GANGNERAU M. N., BENHAïM A., 1982. Sécrétion in vitro de testostérone par des gonades de foetus mâles et femelles de Rat en présence de déhydroépiandrostérone. C.R. Acad. Sci. Paris., 294, Sér. III, 863-865.

PICON R., KTORZA A., 1976. Effect of LH on testosterone production by foetal rat testes in vitro. FEBS Letters, 68, 19-22.

PICON R., PELLOUX M. C., BENHAIIM A., GLOAGUEN F., 1985. Conversion of androgen to estrogen by the rat fetal and neonatal female gonad : effects of dcAMP and FSH. J. Ster. Biochem., 23, 995-1000.

POINTIS G., LATREILLE M. T., CEDARD L., 1980. Gonado-pituitary relationships in the fetal mouse at various times during sexual differentiation. J. Endocrin., 86, 433-488.

POINTIS G., MAHOUDEAU J. A., 1975. Influence des hormones gonadotropes et de I'hypophyse foetale sur la production de testostérone par le testicule foetal de souris de 18 jours en culture organotypique. C.R. Acad. Sci. Paris, 280, Sér. D, 2361-2364.

POINTIS G., MAHOUDEAU J. A., 1976. Demonstration of a pituitary gonadotrophin hormone activity in the male foetal mouse. Acta endocrin., 83, 158-165.

POINTIS G., MAHOUDEAU J. A., 1977. Responsiveness of foetal mouse testis to gonadotrophins at various times during sexual differentiation. J. Endocrin., 74, 149-150.

POINTIS G., MAHOUDEAU J. A., 1979. Etude de l'activité leydigienne et gonadotrope chez l'embryon de souris mâle en fin de gestation. Ann. Endocrin., 40, 431-432.

RAESIDE J. I., 1983. Gonadotrophic stimulation of androgen secretion by the early fetal pig ovary in organ culture. Biol. Reprod., 28, 128-133.

RAESIDE J. I., MIDDLETON A. T., 1979. Development of testosterone secretion in the fetal pig testis. Biol. Reprod., 21, 985-989.

RAESIDE J. I., SIGMAN D. M., 1975. Testosterone levels in early fetal testes of domestic pigs. Biol. Reprod., 13, 318-321.

REYES F. I., BORODITSKY R. S., WINTER J. S. D., FAIMAN C., 1974. Studies on human sexual development. II. Fetal and maternal serum gonadotropin and sex steroid concentrations. J. clin. Endocrin. Metab., 38, 612-617.

SANYAL M. K., VILLEE C. A., 1977. Stimulation of androgen biosynthesis in rat fetal testes in vitro by gonadotropins. Biol. Reprod., 16, 174-181.

SETÁLO G., NAKANE P. K., 1976. Functional differentiation of the fetal anterior pituitary cells in the rat. Endocrin. exper., 10, 155-166.

SHAHA C., GREENWALD G. S., 1983. Development of steroidogenic activity in the ovary of the prepubertal hamster. I. Response to in vivo or in vitro exposure to gonadotropins. Biol. Reprod., 28, 1231-1241.

SHEMESH M., AILENBERG M., MILAgUR F., AYALON N., HANSEL W., 1978. Hormone secretion by cultured bovine pre- and post- implantation gonads. Biol. Reprod., 19. 761-767.

SIITERI P. K., WILSON J. D., 1974. Testosterone formation and metabolism during male sexual differentiation in the human embryo. J. clin. Endocrin. Metab., 38, 113-125.

SILER-KHODR T. M., MORGENSTERN L. L., GREENWOOD F. C., 1974. Hormone synthesis and release from human fetal adenohypophyses in vitro. $J$. clin. Endocrin. Metab., 39, 891905.

SUAREZ-OUIAN C. A., DYM M., MAKRIS A., BRUMBAUGH J., RYAN K. J., CANICK J. A., 1983. Estrogen synthesis by immature rat Sertoli cells in vitro. J. Androl., 4, 203-209.

TERADA N. KURODA H., NAMIKI M., KITAMURA Y., MATSUMOTO K., 1984 . Augmentation of aromatase activity by FSH in ovaries of fetal and neonatal mice in organ culture. J. Ster. Biochem., 20, 741-745.

TOUGARD C., PICART R., TIXIER-VIDAL A., 1977. Cytogenesis of immunoreactive gonadotropic cells in the fetal rat pituitary at light and electron microscope levels. Develop. Biol., 58, 148-163.

TSAI-MORRIS C.-H., AQUILANO D. R., DUFAU M. L., 1985. Cellular localization of rat testicular aromatase activity during development. Endocrinology, 116, 38-46.

TSUJI M., TERADA N., YABUMOTO H., TAKEYAMA M., MATSUMOTO K., 1983. Hormonal 
regulation of activities of 4 -ene- $5 \beta$ and $5 \alpha$-reductases and $17 \beta$-ol-dehydrogenase in immature golden hamster ovary. J. Ster. Biochem., 18, 777-781.

VERHOEVEN G., DIERICKX P., De MOOR P., 1979. Stimulation effect of neurotransmitters on the aromatization of testosterone by Sertoli cell-enriched cultures. Mol. cell. Endocrin., 13, 241. 253.

VEYSSIERE G., BERGER M., JEAN-FAUCHER C., De TURCKHEIM M., JEAN C., 1977. Effect of luteinizing hormone (LH) and $\mathrm{LH}$-releasing hormone (LHRH) on testosterone production in vivo in fetal rabbit testis in late gestation. Biol. Neonate. 32, 327-330.

VEYSSIĖRE G., BERGER M., JEAN-FAUCHER C., De TURCKHEIM M., JEAN C., 1980a. Ontogenèse des relations hypothalamo-hypophyso-testiculaires chez le foetus de lapin. Reprod. Nutr. Dévelop., 20, 235-240.

VEYSSIERE G., BERGER M., JEAN-FAUCHER C., De TURCKHEIM M., JEAN C., 1980b. Ontogeny of pituitary gonadotrophin hormone activity and of testicular responsiveness to gonadotrophins in foetal rabbit. Acta endocrin., 94, 412-418.

VEYSSIĖRE G., BERGER M., JEAN-FAUCHER C., De TURCKHEIM M., JEAN C., 1981. Dosage radioimmunologique de la LH dans I'hypophyse du foetus de Lapin. C.R. Acad. Sci., Paris, 292, Sér. III, 323-326.

VEYSSIÉRE G., BERGER M., JEAN-FAUCHER C., De TURCKHEIM M., JEAN C., 1982. Pituitary and plasma levels of luteinizing hormone and follicle-stimulating hormone in male and female rabbit fetuses. J. Endocrin., 92, 381-387.

WARREN D. W., HALTMEYER G. C., EIK-NES, K. B., 1973. Testosterone in the fetal rat testis. Biol. Reprod., 8, 560-565.

WARREN D. W., HALTMEYER G. C., EIK-NES K. B., 1975. The effect of gonadotrophins on the fetal and neonatal rat testis. Endocrinology, 96, 1226-1229.

WATANABE Y. G., DAIKOKU S., 1979. An immunohistochemical study on the cytogenesis of adenohypophysial cells in fetal rats. Develop. Biol., 68, 557-567.

WENIGER J.-P., CHOURAQUI J., ZEIS A., 1977. Contrôle hypophysaire de la synthèse des androgènes chez l'embryon de Rat. C.R. Acad. Sci. Paris, 284, Sér. D, 199-201.

WENIGER J.-P., CHOURAQUI J., ZEIS A., 1984. Conversion of testosterone and progesterone to oestrone by the ovary of the rat embryo in organ culture. J. Ster. Biochem., 21, 347-349.

WENIGER J.-P., CHOURAQUI J., ZEIS A., 1985. Steroid conversions by the 19-day-old foetal rat ovary in organ culture. Biol. Chem. Hoppe-Sey/er, 366, 555-559.

WENIGER J. P., ZEIS A., 1972. Sur la sécrétion précoce de testostérone par le testicule embryonnaire de Souris. C.R. Acad. Sci., Paris, 275, Sér. D, 1431-1433.

WENIGER J.-P., ZEIS A., 1974. Sur la sensibilité du testicule embryonnaire de Souris à I'hormone lutéinisante, LH. C.R. Acad. Sci. Paris, 279, Sér. D, 1629-1631.

WENIGER J.-P., ZEIS A., 1975a. Influence de la gonadotrophine chorionique sur la synthèse de testostérone par le testicule embryonnaire de Rat. C.R. Acad. Sci. Paris, 280, Sér. D, 18091811.

WENIGER J.-P., ZEIS A., 1975b. Effet des gonadotrophines sur la synthèse d'androgènes par les testicules embryonnaires de Souris et de Rat. Arch. Anat. micr. Morph. exp., 64, 61-66.

WENIGER J.-P., ZEIS A., 1983. Aromatisation de la testostérone par le testicule embryonnaire de Rat. C.R. Acad. Sci. Paris, 296, Sér. III, 293-296.

WENIGER J.-P., ZEIS A., 1985. Comparaison du métabolisme des stéroides par les ovaires de l'embryon de Rat de 19 jours en culture in vitro. Reprod. Nutr. Dévelop., 25, 531-535.

WESSON J. A., GINTHER O. J., 1980. Fetal and maternal gonads and gonadotropins in the pony. Biol. Reprod., 22, 735-743.

WILSON J. D., SIITERI P. K., 1973. Developmental pattern of testosterone synthesis in the fetal gonad of the rabbit. Endocrinology, 92, 1182-1191.

WINTER J. S. D., FAIMAN C., REYES F., 1981. Sexual endocrinology of fetal and perinatal life, 205-253. In : C. R. AUSTIN, R. G. EDWARDS, Mechanisms of sex differentiation in animals and man. Acad. Press.

WORKEWYCH J., CHENG K. W., 1979. Development of glycoprotein hormones and their $\alpha$ - and $\beta$-subunits in bovine fetal pituitary glands. I. Quantitation of thyrotropin, folliclestimulating hormone, and luteinizing hormone by radioligand receptor assays. Endocrino/ogy, 104, 1069-1074. 